\title{
Mechanical properties and water resistance of Vietnamese acacia and rubberwood after thermo-hygro-mechanical modification
}

\author{
Rulong Cao ${ }^{1} \cdot$ Juhani Marttila ${ }^{1} \cdot$ Veikko Möttönen ${ }^{2} \odot \cdot$ Henrik Heräjärvi $^{2} \cdot$ Pekka Ritvanen $^{3} \cdot$ Erkki Verkasalo $^{2}$
}

Received: 13 September 2019 / Published online: 18 June 2020

(c) The Author(s) 2020

\begin{abstract}
Low density and poor mechanical performance often limit utilisation of sawn wood from fast-growing plantation forests. Thermo-hygro-mechanical modification (THM) of timber is one innovation for improving the properties of light-weight wood species. The objective of this study was to determine the effects of THM and subsequent thermal treatment on dry density, modulus of elasticity (MOE), compression strength, Brinell hardness, and swelling behaviour in immersion tests on two fast-growing Vietnamese species, acacia (Acacia mangium) and rubberwood (Hevea brasiliensis). Test boards were modified in an industrial kiln, in which a tangential thickness compression of $14 \%$ and $12 \%$ were aimed for acacia and rubberwood, respectively, either with or without subsequent thermal treatment at $210{ }^{\circ} \mathrm{C}$. Dry density, MOE, Brinell hardness, compression strength, and dimensional changes in water immersion tests of specimens were measured from the modified and unmodified reference materials, the latter ones being kiln dried at $50{ }^{\circ} \mathrm{C}$. The results showed that the responses of the mechanical properties were more evident for rubberwood than for acacia. In rubberwood, the MOE and compression strength of wood thermo-hygro-mechanically modified with or without thermal treatment were higher than those of kiln-dried reference specimens throughout the thickness profile. In case of acacia, similar differences between the modified and reference specimens were observed only in the surface layer. Density and Brinell hardness of thermo-hygro-mechanically modified rubberwood were higher than those of reference specimens, but after thermal treatment they did not differ from (acacia) or were lower (rubberwood) than those of THM specimens. Post-compression thermal treatment increased the hydrophobicity of THM specimens.
\end{abstract}

\section{Introduction}

Fast-growing acacia (Acacia mangium) and rubber tree (Hevea brasiliensis) plantations have been successfully commercialised in Southeast Asia thanks to their adaptability to various climatic and soil conditions and short rotation period (e.g., Nguyen 2013; Hai et al. 2015). Their applications in wood product industries are still limited by the relatively low density and poor dimensional stability of wood (Mohammed Raphy et al. 2011; Teoh et al. 2011; Nambiar et al.

Veikko Möttönen

veikko.mottonen@luke.fi

1 School of Forest Sciences, University of Eastern Finland (UEF), 80100 Joensuu, Finland

2 Production Systems, Natural Resources Institute Finland (Luke), 80100 Joensuu, Finland

3 KWS Timber Tech Ltd, 70100 Kuopio, Finland
2014; Shukla and Sharma 2018). Consequently, their timber is mostly used by kraft pulping industries or as firewood.

Mechanical properties of wood are highly dependent on wood density (Pelit et al. 2018). Densification or compression in transverse direction is considered as an effective and environmentally friendly method to increase the density of wood. Densification reduces the void volume of lumens and reshapes the morphology of cells without loss of lignin, resulting in improvement of mechanical properties such as modulus of elasticity, compression strength, tensile strength, hardness, and abrasion resistance of low-density wood species (Anshari et al. 2011; Sandberg et al. 2013). However, once the atmospheric humidity and heat in the compression process terminate, elastic energy stored in microfibrils of compressed wood will be released, resulting in springing back towards its original shape, which is defined as "shape memory" or "set recovery" (Navi and Sandberg 2012). This phenomenon is considered as the biggest problem of the process, regardless of the mechanical property elevation of compressed wood (e.g., Möttönen et al. 2015). 
It is crucial to improve the dimensional stability of densified wood in the direction of compression to ensure further processing and usability of end products. Although the shape memory cannot be totally eliminated, it can be restricted by adjusting the heat, compressive force, and pressing time during the densification process (e.g., Navi and Girardet 2000; Kúdela et al. 2018). Depending on the combination of relative humidity and temperature used during the process, densification can be categorised into two types, thermo-hygro-mechanical modification (THM) and thermo-mechanical modification (TM). In THM process, atmospheric temperature and humidity are well-controlled and the compressive forces are subjected to wood in radial or tangential directions (Dogu et al. 2010; Sandberg and Kutnar 2016). In TM process, the compression takes place in an open system without detailed control of relative humidity, being also widely applied in the industries (Kúdela et al. 2018). If the conditions are well-controlled in THM, higher values of density and stronger surface layers would be achieved, resulting in surfaces well applicable to flooring, furniture, and decorative uses (Gao et al. 2016).

Post-compression thermal treatment is known as another way to improve the dimensional stability of compressed wood, thereby offsetting the shape memory of THM modified wood (e.g., Gong et al. 2010; Möttönen et al. 2013; Yan and Morrell 2014; Möttönen et al. 2015; Sandberg and Kutnar 2016; Marttila et al. 2017; Sandberg et al. 2017). During the thermal treatment process, wood is exposed to high temperature $\left(\geq 160^{\circ} \mathrm{C}\right)$ (e.g., Millet and Gerhards 1972; Hillis 1975; Kocaefe et al. 2015). In this process, the structure of chemical components in wood will be altered to a specific extent, thereby affecting other properties of wood (e.g., hygroscopicity, equilibrium moisture content, dimensional stability, fungal and insect resistance, mechanical properties, colour, and odour) (e.g., Sandberg et al. 2017). Optimised parameters during the thermal treatment processes need to be designed for specific species, considering their inherent properties (Sandberg et al. 2013).
The objective of this study was to investigate the effect of thermo-hygro-mechanical modification and subsequent thermal treatment on selected mechanical properties, i.e., modulus of elasticity, compression strength, and Brinell hardness, and extreme-condition swelling behaviour of plantation-grown Vietnamese acacia and rubberwood.

\section{Materials and methods}

Frozen logs of two different tree species from Vietnam, acacia (Acacia mangium) and rubber tree (Hevea brasiliensis), were transported by sea freight to Juankoski, Finland, where they were melted, sawn into boards, and, finally, thermohygro-mechanically (THM) modified. The pilot modification kiln patented by KWS Timber Tech Ltd (Finland) allows wood drying, mechanical compression, and subsequent thermal treatment in one single kiln unit. Different combinations of various process phases can be achieved by adjusting parameters such as temperature, hydraulic pressure, relative humidity, steaming, and treatment time. The boards were divided into six groups: four groups for different modification treatments and two reference groups, which were dried at $50{ }^{\circ} \mathrm{C}$ without any modification (Table 1 ).

In the kiln, the boards were placed between perforated aluminium plates, where the compression takes place evenly on the boards and their moisture content can be indirectly controlled by the air circulation rate between the plates (Fig. 1). Drying and hydraulic compression proceeded simultaneously. The drying temperature was steadily increased up to $130{ }^{\circ} \mathrm{C}$ for acacia and $120{ }^{\circ} \mathrm{C}$ for rubberwood, and the nominal degrees of mechanical compression (thickness change/original thickness) for acacia and rubberwood were set to $14 \%$ and $12 \%$, respectively. The different values of modification parameters were used due to difference in the initial basic density between the species. After the drying and mechanical compression, a three-hour thermal treatment at $210{ }^{\circ} \mathrm{C}$ was instantly applied to one group of the boards of both

Table 1 Treatments and number of boards in the six treatment groups

\begin{tabular}{|c|c|c|c|c|c|}
\hline Code & Group & Treatment & $\begin{array}{l}\text { Number } \\
\text { of boards }\end{array}$ & $\begin{array}{l}\text { Compres- } \\
\text { sion degree } \\
(\%)\end{array}$ & $\begin{array}{l}\text { Time and tem- } \\
\text { perature in thermal } \\
\text { treatment }\end{array}$ \\
\hline A & Unmodified acacia & Reference, $50^{\circ} \mathrm{C}$ oven-drying & 14 & - & - \\
\hline $\mathrm{AC}$ & Thermo-hygro-mechanically modified acacia & Compression, kiln drying & 10 & 14 & - \\
\hline ACT & $\begin{array}{l}\text { Thermo-hygro-mechanically modified acacia with } \\
\text { subsequent thermal treatment }\end{array}$ & Compression and thermal treatment & 9 & 14 & $210^{\circ} \mathrm{C}, 3 \mathrm{~h}$ \\
\hline $\mathrm{R}$ & Unmodified rubberwood & Reference, $50^{\circ} \mathrm{C}$ oven-drying & 12 & - & - \\
\hline $\mathrm{RC}$ & Thermo-hygro-mechanically modified rubberwood & Compression, kiln drying & 11 & 12 & - \\
\hline $\mathrm{RCT}$ & $\begin{array}{l}\text { Thermo-hygro-mechanically modified rubberwood } \\
\text { with subsequent thermal treatment }\end{array}$ & Compression and thermal treatment & 10 & 12 & $210^{\circ} \mathrm{C}, 3 \mathrm{~h}$ \\
\hline
\end{tabular}




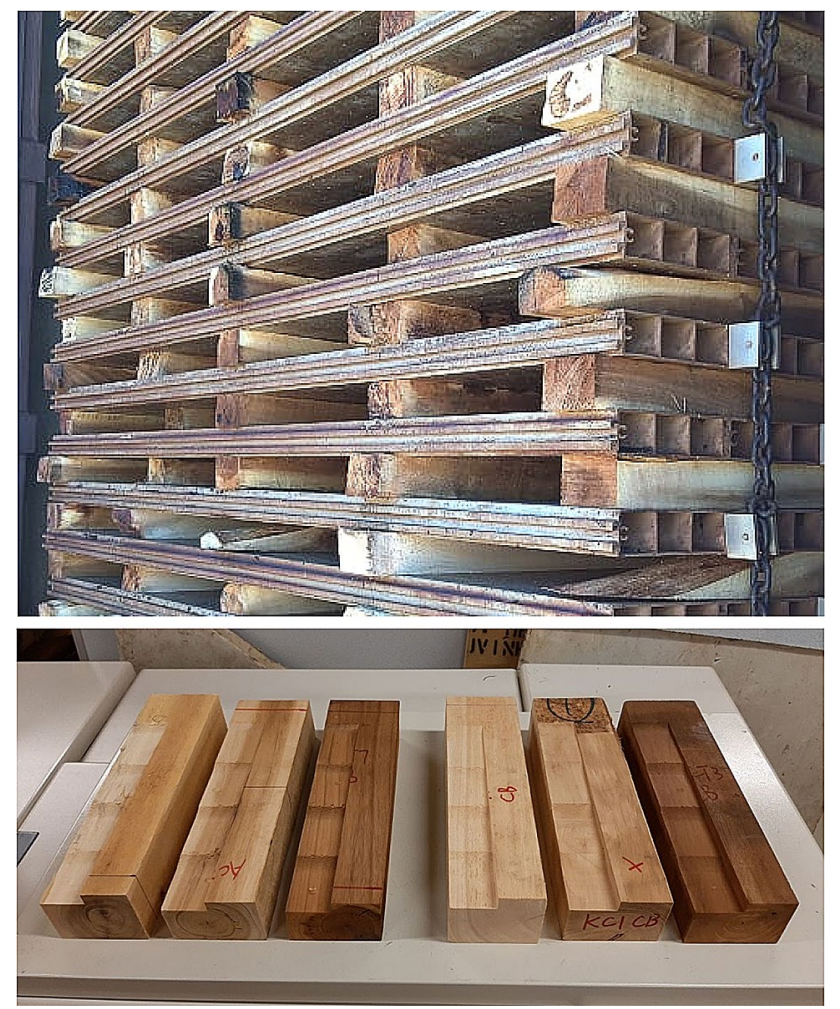

Fig. 1 Above: A set of acacia boards $(60 \times 80 \times 1200 \mathrm{~mm})$ after the compression process loaded in the THM treatment kiln. Below: Brinell hardness test specimens of reference and modified acacia and rubberwood. From the left: A, AC, ACT, R, RC, RCT

species (compressed and thermally treated acacia and rubberwood). During this process, certain amount of steam was applied in the kiln to protect the boards from oxidation reactions. After the thermal treatment process, the system was cooled down, and the compression was released.

Moisture content (MC, \%) and dry density $\left(\rho_{b}, \mathrm{~kg} / \mathrm{m}^{3}\right)$ of the specimens from all boards were determined by the gravimetric method. The dimensions of the specimens, which were sawn from one end of each modified and unmodified board, were $50 \times 80 \times 50 \mathrm{~mm}$ and $60 \times 80 \times 50 \mathrm{~mm}$ (thickness $\times$ width $\times$ length), respectively.

Matertest model FMT-MEC $100 \mathrm{kN}$ (Finland) material testing device was used to carry out the modulus of elasticity (MOE) test and to record the MOE value of each board. Prior to the MOE test, the boards of groups A (acacia) and $\mathrm{R}$ (rubberwood) were dried in an oven at a temperature of $50{ }^{\circ} \mathrm{C}$ for two weeks, while those of AC (compressed acacia), ACT (compressed and thermally treated acacia), RC (compressed rubberwood), RCT (compressed and thermally treated rubberwood) were conditioned indoors for two weeks in order to achieve the adequate moisture level (12 $\pm 5 \%)$ required by the testing standards.

$\operatorname{MOE}\left(E_{w}, \mathrm{MPa}\right)$ was determined using static three-point bending test according to the standard ISO 13061-4, where the applied forces caused the deflection in the mid-span of each board:

$E_{W}=\frac{P l^{3}}{4 b h^{3} f}$

where $P$ is the load equal to the difference between the upper and lower limits of loading $(\mathrm{N}), l$ is the span $(\mathrm{mm}), b$ is the width of the test specimens ( $\mathrm{mm}), h$ is the height of the test specimens $(\mathrm{mm})$, and $f$ is the deflection between the upper and lower limits of loading $(\mathrm{mm})$. MOE values were determined from the full-length boards using the span of $750 \mathrm{~mm}$ and $840 \mathrm{~mm}$ for modified and reference specimens, respectively. Different spans were used to maintain equal height-to-length ratio of 1:14 between the untreated and treated specimens. After this, specimens were utilised in measurements of density, compression strength, swelling behaviour, and Brinell hardness.

Compression strength parallel to grain was determined using Zwick Z050 (Germany) material testing machine according to ISO 13061-12. All the samples were stored in the conditioning chamber at $20{ }^{\circ} \mathrm{C}$ and $65 \%$ relative humidity until they reached equilibrium moisture content (EMC), i.e., the mass did not change anymore. The ultimate strength in compression $(\sigma, \mathrm{MPa})$ was determined according to the standard ISO 13061-17 using gradually increasing load in parallel to the grain direction:

$\sigma=\frac{F_{\max }}{a b}$

where $F_{\max }$ is the maximum load force (N), $a$ and $b$ are the cross-sectional dimensions of the test specimen (mm). Nominal dimensions of the compression test specimens were $20 \times 20 \times 60 \mathrm{~mm}$ (radial $\times$ tangential $\times$ longitudinal).

The MOE in bending and the ultimate compression strength were computationally adjusted to $12 \%$ moisture content using the following formulae (ISO 13061-4), which are valid for moisture content of $12 \pm 5 \%$ :

$E_{12}=\frac{E_{W}}{1-\alpha(W-12)}$

$\sigma_{12}=\sigma(1+\alpha(W-12))$

where $E_{12}$ is the calibrated MOE value at the moisture content of $12 \%(\mathrm{MPa}), \sigma_{12}$ is the calibrated compression strength at the moisture content of $12 \%(\mathrm{MPa}), \alpha$ is the correction factor $(0.02)$ for the moisture content, $W$ is the moisture content of wood during the test, determined according to ISO 13061-1.

Prior to the immersion test, all the test specimens were stabilised in the normal climate chamber at $20{ }^{\circ} \mathrm{C}$ and $65 \%$ relative humidity until their EMC was reached. After 
that, the initial length, width, and thickness of the specimens were measured using calliper. Next, the specimens were soaked in buckets filled with tap water and stored at room temperature for 14 days. The dimensions were measured from the same positions once again after the 14 days of soaking. The dimensional changes were determined according to the formula:

$\alpha=\frac{L_{1}-L_{0}}{L_{0}} \times 100 \%$

where $\alpha$ is the swelling rate in length, width, and thickness $(\%), L_{0}$ is the initial dimension (length, width, and thickness, $\mathrm{mm}$ ), $L_{l}$ is the dimension (length, width, and thickness, $\mathrm{mm}$ ) after the 14-day immersion.

Brinell hardness $(H B)\left(\mathrm{kg} / \mathrm{mm}^{2}\right)$ of the test specimens was determined according to the standard EN 1534 (2010):

$H B=\frac{2 F}{g \pi D\left(D-\sqrt{D^{2}-d^{2}}\right)}$

where $F$ is the maximum load applied $(1000 \mathrm{~N}), g$ is the acceleration of gravity $\left(9.81 \mathrm{~m} / \mathrm{s}^{2}\right), D$ is the diameter of the indenter $(10 \mathrm{~mm}), d$ is the average value of the diameter $\left[\left(d_{1}+d_{2}\right) / 2\right]$ on specimen surface $(\mathrm{mm}), d_{1}$ and $d_{2}$ being the diameters of the residual indentation along the grain and across the grain, measured with calliper.

\section{Results and discussion}

\subsection{Dry density}

Significant differences were found between $\mathrm{R}$ and $\mathrm{RC}$, as well as RC and RCT, suggesting that THM had a positive effect on dry density of rubberwood (increase by $7.3 \%$ ), while subsequent thermal treatment decreased the dry density from RC to RCT by $7.5 \%$ (Tables 2,3 ). This might indicate that the THM changed the structure of rubberwood tissue to contain less void space and more solid cell wall per unit volume, thereby increasing the dry density (e.g., Kutnar et al. 2008; Fang et al. 2012). The post-compression thermal treatment caused degradation of holocellulose, in particular hemicellulose, and evaporation of most extractives and volatile organic compounds (VOCs) resulting in mass loss of cell walls (Sandberg and Kutnar 2016; Severo et al. 2016; Shukla and Sharma 2014).

No significant differences were observed between the experimental groups of acacia. High initial moisture content or inappropriate compression temperature, pressure, or time might lead to the failure of compression, in which the whole thickness profile of acacia specimens was not totally subjected to the compressive pressure (see: Kúdela et al. 2018). Another potential reason is that the strong springback effect in AC specimens counterbalanced the positive effect of compression on the density of acacia (Pelit et al. 2018). The sea freight of frozen logs at green state may
Table 2 Mean values $(\bar{x})$ and standard deviations $(\sigma)$ of physical and mechanical properties

\begin{tabular}{|c|c|c|c|c|c|c|c|c|c|c|c|c|}
\hline \multirow[t]{2}{*}{ Treatment } & \multicolumn{2}{|l|}{$\begin{array}{l}\mathrm{MC} \\
(\%)\end{array}$} & \multicolumn{2}{|c|}{$\begin{array}{l}\text { Dry } \\
\text { density } \\
\left(\mathrm{kg} / \mathrm{m}^{3}\right)\end{array}$} & \multicolumn{2}{|c|}{$\begin{array}{l}\mathrm{MOE} \\
(\mathrm{MPa})\end{array}$} & \multicolumn{2}{|c|}{$\begin{array}{l}\mathrm{HB} \\
(\mathrm{kg} / \\
\left.\mathrm{mm}^{2}\right)\end{array}$} & \multicolumn{2}{|c|}{$\begin{array}{l}\text { CS-C } \\
(\mathrm{MPa})\end{array}$} & \multicolumn{2}{|c|}{$\begin{array}{l}\text { CS-S } \\
(\mathrm{MPa})\end{array}$} \\
\hline & $\bar{x}$ & $\sigma$ & $\bar{x}$ & $\sigma$ & $\bar{x}$ & $\sigma$ & $\bar{x}$ & $\sigma$ & $\bar{x}$ & $\sigma$ & $\bar{x}$ & $\sigma$ \\
\hline Untreated (A) & 22.6 & 11.6 & 571 & 65 & 10.6 & 2.3 & 2.6 & 0.9 & 49.6 & 2.0 & 49.6 & 2.0 \\
\hline Compression (AC) & 7.1 & 2.2 & 590 & 79 & 9.8 & 1.2 & 2.8 & 1.1 & 56.5 & 2.8 & 61.2 & 1.9 \\
\hline Compression and thermal (ACT) & 3.1 & 0.4 & 553 & 70 & 10.6 & 1.0 & 1.9 & 0.6 & 58.8 & 1.9 & 61.0 & 3.1 \\
\hline Untreated (R) & 7.9 & 1.3 & 620 & 40 & 8.1 & 0.8 & 2.5 & 0.5 & 49.7 & 1.4 & 49.7 & 1.4 \\
\hline Compression (RC) & 6.0 & 0.3 & 665 & 40 & 11.3 & 1.4 & 3.9 & 0.9 & 59.4 & 1.9 & 59.8 & 2.4 \\
\hline Compression and thermal (RCT) & 4.2 & 0.2 & 615 & 38 & 11.1 & 0.8 & 2.3 & 0.4 & 60.8 & 1.7 & 63.5 & 1.2 \\
\hline
\end{tabular}

Table 3 Significance levels of the differences in dry density, MOE, Brinell hardness (HB), compression strength in the core (CS-C) and surface layer (CS$\mathrm{S}$ ), and swelling ( $\mathrm{T}$ ) between the different treatment groups

\begin{tabular}{lllllll}
\hline Pair & Dry density & MOE & HB & CS-C & CS-S & Swelling T \\
\hline A-AC & 0.786 & 0.478 & 0.538 & 0.176 & $0.004^{*}$ & $0.000^{*}$ \\
A-ACT & 0.826 & 0.998 & $0.008^{*}$ & 0.124 & $0.021^{*}$ & $0.012^{*}$ \\
AC-ACT & 0.493 & 0.584 & $0.001^{*}$ & 0.974 & 1.000 & 0.085 \\
R-RC & $0.027^{*}$ & $0.000^{*}$ & $0.000^{*}$ & $0.007^{*}$ & $0.005^{*}$ & $0.000^{*}$ \\
R-RCT & 0.959 & $0.000^{*}$ & 0.578 & $0.002^{*}$ & $0.000^{*}$ & $0.000^{*}$ \\
RC-RCT & $0.019^{*}$ & 0.806 & $0.000^{*}$ & 0.981 & 0.597 & $0.002^{*}$ \\
\hline
\end{tabular}

*Significancy at $p \leq 0.05$ 
also have had adverse effects on physical and mechanical properties of wood, for example, by causing frost cracks (Kubler 1988). The higher moisture content of green acacia logs $(65.8 \%)$ compared to green rubber tree logs (47.9\%) might have resulted in the observed differences between the species.

\subsection{Modulus of elasticity (MOE)}

Compared to the reference material, THM and THM with subsequent thermal treatment resulted in an increase in the MOE of rubberwood of $39.5 \%$ and $35.9 \%$, respectively, while no increase was observed in acacia (Tables 2, 3). The differences between species might partly be caused by the differences in the chemical composition of wood. The chemical and mechanical properties have been found to correlate and to be dependent on the height and clone of rubber trees (Riyaphan et al. 2015).

Several studies have shown that densification is an effective way to improve the mechanical properties of wood (e.g., Kutnar et al. 2008; Anshari et al. 2011; Fang et al. 2012; Möttönen et al. 2015; Gao et al. 2016). Generally, the bending stiffness of wood increases proportionally to density increment as a result of compression (Kutnar 2012). Increasing temperature up to $150{ }^{\circ} \mathrm{C}$ during compression also has a positive effect on MOE value of wood as it reduces the spring-back effect of compressed wood, although the increase in MOE caused by high temperature is not as obvious as that caused by high compression ratio (Tabarsa and Chui 1997; Lamason and Gong 2007).

The effect of thermal treatment on MOE is dependent on wood species, temperature, initial moisture content, surrounding atmosphere, and reaction time (Mitchell 1988). Therefore, the effects can be either positive (Fang et al. 2012; Shi et al. 2007; Heräjärvi 2009) or negative (Gong et al. 2010; Johansson and Morén 2006), depending on the parameters applied during the process. Thermo-hygro-mechanical modification followed by thermal treatment increased the MOE of green European aspen (Populus tremula) by $18 \%$ and that of Silver birch (Betula pendula) by $6 \%$ with densification degrees of $30 \%$ and $10 \%$, respectively (Marttila et al. 2016). High temperature and long processing time may decrease the MOE due to the deterioration of wood components, particularly hemicellulose (Yan and Morrell 2014; Korkut and Aytin 2015). In addition, since the proportion of amorphous cellulose decreases with increasing temperature (e.g., Sivonen et al. 2002; Yildiz and Gümüşkaya 2007; Cai et al. 2018), an increase in crystallinity of cellulose may cause an increase in the MOE. However, increase in MOE is associated with the reduced moisture content in the modified wood (Xie et al. 2013). Usually moisture content is negatively correlated with MOE below the FSP (Kretschmann 2010). The dependence of MOE or compression strength on moisture content may differ between modified and unmodified wood. Therefore, the computational adjustment of MOE and compression strength values to $12 \%$ moisture content may not be proportional between treatments. Detailed characterization of chemical changes and crystallisation would require techniques such as Fourier transform infrared spectroscopy (FTIR) or differential scanning calorimetry (DSC). Diouf et al. (2011) found cleavage of hemicellulose and removal of high carbon compounds and extractives using Fourier transform infrared spectroscopy (ATR-FTIR) and $\mathrm{X}$-ray photoelectron spectroscopy (XPS), respectively.

Decrease in MOR values after thermal treatment of wood has been noticed in acacia (Wahab et al. 2012) rubberwood (Zhou et al. 2019) and in several other species (e.g., Millett and Gerhards 1972; Heräjärvi 2009; Widmann et al. 2012). Marttila et al. (2016) observed that subsequent thermal treatment at $190{ }^{\circ} \mathrm{C}$ after thermo-hygro-mechanical modification of green timber reduced MOR values of European aspen and Silver birch by $10 \%$ and $16 \%$, respectively. The decrease in bending strength might be due to the hemicellulose degradation (Kass et al. 1970; LeVan et al. 1990; Kocaefe et al. 2008). Bending strength was not measured in this study.

\subsection{Compression strength}

Both THM and THM with subsequent thermal treatment increased the compression strength of surface specimens of acacia by $23 \%$, while the change in compression strength of core specimens was insignificant. In case of rubberwood, the increments in compression strength of surface and core specimens were $20 \%$ and $25 \%$, respectively (Tables 2, 3).

There are several explanations for the increment of compression strength achieved by thermal treatment. Firstly, increase in crystallinity increases the stiffness of wood in its longitudinal direction (Anderson et al. 2005; Yildiz et al. 2006). Secondly, increased cross-linking of lignin polymer network can better connect and stiffen cellulose fibrils and prevent them from bending or crashing when they are subjected to compressive forces, thereby increasing the longitudinal compression strength of wood (Boonstra et al. 2007).

\subsection{Swelling behaviour in immersion test}

The results showed that modified specimens of both species swell more in the direction of compression than the untreated references: $385 \%, 218 \%, 172 \%$, and $114 \%$ higher dimensional changes were detected in AC, ACT, RC, and RCT, respectively, compared to their references (Tables 3, 4). It seems that the irreversible set recovery phenomenon explained the swelling in the modified specimens, in addition to the reversible hygroscopicity of wood itself (Fang et al. 2012). 
Table 4 Mean values $(\bar{x})$, standard deviations $(\sigma)$, and significance levels $(p)$ (compared with untreated wood) of dimensional stability in tangential (T), longitudinal (L) and radial (W) directions

\begin{tabular}{|c|c|c|c|}
\hline Treatment & Swelling T & Swelling L & Swelling W \\
\hline \multicolumn{4}{|l|}{ A } \\
\hline $\bar{x}$ & $1.1 \%$ & $0.2 \%$ & $0.7 \%$ \\
\hline$\sigma$ & $0.7 \%$ & $0.1 \%$ & $0.5 \%$ \\
\hline$p$ & $0.001 *$ & 0.666 & 0.202 \\
\hline \multicolumn{4}{|l|}{$\mathrm{AC}$} \\
\hline $\bar{x}$ & $5.4 \%$ & $0.1 \%$ & $0.9 \%$ \\
\hline$\sigma$ & $1.5 \%$ & $0.3 \%$ & $0.6 \%$ \\
\hline$p$ & $0.000^{*}$ & 0.978 & 0.616 \\
\hline \multicolumn{4}{|l|}{ ACT } \\
\hline $\bar{x}$ & $3.5 \%$ & $0.1 \%$ & $1.3 \%$ \\
\hline$\sigma$ & $2.9 \%$ & $0.1 \%$ & $0.7 \%$ \\
\hline$p$ & $0.045^{*}$ & 0.996 & $0.022 *$ \\
\hline \multicolumn{4}{|l|}{$\mathrm{R}$} \\
\hline $\bar{x}$ & $2.7 \%$ & $0.1 \%$ & $2.3 \%$ \\
\hline$\sigma$ & $0.8 \%$ & $0.3 \%$ & $1.1 \%$ \\
\hline$p$ & $0.000^{*}$ & 0.958 & $0.001 *$ \\
\hline \multicolumn{4}{|l|}{$\mathrm{RC}$} \\
\hline $\bar{x}$ & $7.4 \%$ & $-0.1 \%$ & $1.3 \%$ \\
\hline$\sigma$ & $1.1 \%$ & $0.1 \%$ & $0.4 \%$ \\
\hline$p$ & $0.000 *$ & 0.987 & 0.231 \\
\hline \multicolumn{4}{|l|}{ RCT } \\
\hline $\bar{x}$ & $5.8 \%$ & $-0.0 \%$ & $1.8 \%$ \\
\hline$\sigma$ & $0.9 \%$ & $0.1 \%$ & $0.4 \%$ \\
\hline$p$ & $0.000 *$ & 1.000 & $0.001 *$ \\
\hline
\end{tabular}

*Significancy at $p \leq 0.05$

As much as $21 \%$ lower thickness swelling was detected in RCT specimens compared with RC specimens. Thus, the set-recovery of compressed rubberwood was partially eliminated by thermal treatment (Table 4). This might be explained by the following mechanisms: firstly, thermal treatment above $200{ }^{\circ} \mathrm{C}$ temperature can increase the cross-linking network in lignin, which increases the hydrophobicity of wood and reduces its swelling (Santos 2000). Secondly, the stored elastic stresses are released because of degradation of hemicellulose at high temperature (Navi and Sandberg 2012). Elimination of some hygroscopic hydroxyl groups due to the depolymerisation of carbohydrates explains the improved hydrophobicity in thermally treated wood (Xie et al. 2013). In addition, in cellulose components, amorphous regions in cellulose are degraded due to acid catalysis at high temperature, which increases the crystallinity and thereby decreases the accessibility of water molecules in hydroxyl groups (e.g., Cai et al. 2018; Kúdela et al. 2018).

\subsection{Brinell hardness}

An average increment of 58\% in Brinell hardness was detected in RC specimens, whereas no difference was observed between A and AC (Tables 2, 3). Flattening of fibre lumens and vessels in THM may increase the Brinell hardness of wood (Fang et al. 2012). However, a slight loss of Brinell hardness takes place due to increased temperature during the thermo-hygro-mechanical modification (Fang et al. 2012). Typically, higher degree of compression leads to higher Brinell hardness value, although Rautkari et al. (2013) argued that Brinell hardness is mainly influenced by the density and hardness of the surface layer. In addition to varying densities among wood species, other factors such as modification temperature, final density, moisture content, techniques of measurement, and measuring conditions (e.g., load level, loading time) also influence the results of surface hardness (e.g., Holmberg 2000; Gašparík et al. 2016).

On the other hand, compared to $\mathrm{AC}$ and $\mathrm{RC}$, subsequent thermal treatment caused the reduction in Brinell hardness in ACT and RCT by $33 \%$ and $41 \%$, respectively, which was probably due to the deterioration of cell wall structures (Pelit et al. 2015). High temperature and long processing time typically result in greater reduction in Brinell hardness because of the degradation of hemicellulose and lignin at high temperatures (Fang et al. 2012; Salca and Hiziroglu 2014). In addition, reduction in hardness due to heat treatment was found to be highest for wood species with high density (Kesik et al. 2014; Salca and Hiziroglu 2014). Junkkonen and Heräjärvi (2006) also pointed out that thermal treatment alters the character of hardness: because of the loss in elasticity, the indentation on the thermally modified wood surface remains, and unlike in unmodified wood, virtually no springback of the indentation takes place in the course of time. Therefore, even if the measured Brinell hardness value may be identical, the end use related effects of any indentation are far more critical in thermally modified wood.

\section{Conclusion}

Thermo-hygro-mechanical modification is a potential technique to improve some properties of rubberwood (density, stiffness, compression strength, Brinell hardness) and acacia (surface compression strength). However, modified wood swells more than non-modified wood under extreme ambient conditions. Post-compression thermal treatment improves the dimensional stability under such conditions, but reduces the hardness of the surface.

The unfavourable effects of any single modification method can be partially compensated by applying combinations of modification methods and appropriate process parameters. Further experiments are needed to investigate 
the influence of treatment time, compressive force, and modification temperature on acacia and rubberwood properties. Detailed analysis on the economics of thermo-hygromechanical modification process would provide a basis for planning wood modification investments in Vietnam.

Acknowledgements Open access funding provided by Natural Resources Institute Finland (LUKE). The study materials and related processing and logistics costs were covered by KWS Timber Tech Ltd, Kuopio, Finland. The study materials were modified using the thermohygro-mechanical TMTM ${ }^{\mathrm{TM}}$ process of KWS Timber Tech Ltd. The experiments were carried out at the Natural Resources Institute Finland (LUKE), Joensuu, and the University of Eastern Finland (UEF), Joensuu. The authors express their gratitude to these institutions and their personnel who provided support to this study.

\section{Compliance with ethical standards}

Conflict of interest On behalf of all authors, the corresponding author states that there is no conflict of interest.

Open Access This article is licensed under a Creative Commons Attribution 4.0 International License, which permits use, sharing, adaptation, distribution and reproduction in any medium or format, as long as you give appropriate credit to the original author(s) and the source, provide a link to the Creative Commons licence, and indicate if changes were made. The images or other third party material in this article are included in the article's Creative Commons licence, unless indicated otherwise in a credit line to the material. If material is not included in the article's Creative Commons licence and your intended use is not permitted by statutory regulation or exceeds the permitted use, you will need to obtain permission directly from the copyright holder. To view a copy of this licence, visit http://creativecommons.org/licenses/by/4.0/.

\section{References}

Andersson S, Serimaa R, Väänänen T, Paakkari T, Jämsä S, Viitaniemi P (2005) X-ray scattering studies of thermally modified Scots pine (Pinus sylvestris L.). Holzforschung 59:422-427

Anshari B, Guan Z, Kitamori A, Jung K, Hassel I, Komatsu K (2011) Mechanical and moisture-dependent swelling properties of compressed Japanese cedar. Constr Build Mater 25(4):1718-1725

Boonstra M, Van Acker J, Tjeerdsma B, Kegel E (2007) Strength properties of thermally modified softwoods and its relation to polymeric structural wood constituents. Ann For Sci 64(7):679-690

Cai C, Antikainen J, Luostarinen K, Mononen K, Heräjärvi H (2018) Wetting-induced changes in thermally modified Scots pine and Norway spruce wood surface. Wood Sci Technol 52(5):1181-1193

Diouf PN, Stevanovic T, Cloutier A, Fang C-H, Blanchet P, Koubaa A, Mariotti N (2011) Effects of thermo-hygro-mechanical densification on the surface characteristics of trembling aspen and hybrid poplar wood veneers. Appl Surf Sci 257:3558-3564

Dogu D, Tirak K, Candan Z, Unsal O (2010) Anatomical investigation of thermally compressed wood panels. BioResources 5(4):2640-2663

EN 1534 (2010) Wood flooring - determination of resistance to indentation - test method. European Committee for Standardization, Brussels
Fang CH, Mariotti N, Cloutier A, Koubaa A, Blancet P (2012) Densification of wood veneers by compression combined with heat and steam. Eur J Wood Prod 70(1):155-163

Gao Z, Huang R, Lu J, Chen Z, Guo F, Zhan T (2016) Sandwich compression of wood: control of creating density gradient on lumber thickness and properties of compressed wood. Wood Sci Technol 50(4):833-844

Gašparík M, Gaff M, Šafaříková L, Vallejo CR, Svoboda T (2016) Impact bending strength and Brinell hardness of densified hardwoods. BioResources 11(4):8638-8652

Gong M, Lamason C, Li L (2010) Interactive effect of surface densification and post-heat-treatment on aspen wood. J Mater Process Technol 210(2):293-296

Hai PH, Duong LA, Toan NQ, Ha TTT (2015) Genetic variation in growth, stem straightness, pilodyn and dynamic modulus of elasticity in second-generation progeny tests of Acacia mangium at three sites in Vietnam. New For 46(4):577-591

Heräjärvi H (2009) Effect of drying technology on aspen wood properties. Silva Fenn 43(3):433-445

Hillis WE (1975) The role of wood characteristics in high temperature drying. J Inst Wood Sci 7:60-67

Holmberg H (2000) Influence of grain angle on Brinell hardness of Scots pine (Pinus sylvestris L.). Holz Roh Werkst 58(1):91-95

Johansson D, Morén T (2006) The potential of colour measurement for strength prediction of thermally treated wood. Holz Roh Werkst 64(2):104-110

Junkkonen R, Heräjärvi H (2006) Physical properties of European and hybrid aspen wood after three different drying treatments. In: Kurjatko S, Kudela J, Lagana R (eds) Proceedings of the 5th international symposium wood structure and properties '06, pp 257-263, Arbora Publishers, Sliač-Sielnica, Slovakia, 3-6 Sept 2006

Kass A, Wangaard FF, Schroeder HA (1970) Chemical degradation of wood: the relationship between strength retention and pentosan content. Wood Fiber 2(1):31-39

Kesik HI, Korkut S, Hiziroglu S, Sevik H (2014) An evaluation of properties of four heat treated wood species. Ind Crops Prod 60:60-65

Kocaefe D, Shi JL, Yang D, Bouazara M (2008) Mechanical properties, dimensional stability, and mold resistance of heat-treated jack pine and aspen. For Prod J 58(6):88-93

Kocaefe D, Huang X, Kocaefe Y (2015) Dimensional stabilization of wood. Curr For Rep 1(3):151-161

Korkut S, Aytin A (2015) Evaluation of physical and mechanical properties of wild cherry wood heat-treated using the thermowood process. Maderas: Ciencia y tecnología 17(1):171-178

Kretschmann DE (2010) Mechanical properties of wood. Madison, U.S. Department of Agriculture, Forest Service, Forest Products Laboratory: General technical report FPL-GTR-190

Kubler H (1988) Frost cracks in stems of trees. Arboric J 12(2):163-175

Kúdela J, Rousek R, Rademacher P, Rešetka M, Dejmal A (2018) Influence of pressing parameters on dimensional stability and density of compressed beech wood. Eur J Wood Prod 76(4):1241-1252

Kutnar A (2012) Compression of wood under saturated steam, superheated steam, and transient conditions at $150{ }^{\circ} \mathrm{C}, 160{ }^{\circ} \mathrm{C}$, and 170 ${ }^{\circ} \mathrm{C}$. Wood Sci Technol 46(1):73-88

Kutnar A, Kamke FA, Sernek M (2008) The mechanical properties of densified VTC wood relevant for structural composites. Holz Roh Werkst 66(6):439-446

Lamason C, Gong M (2007) Optimization of pressing parameters for mechanically surface-densified aspen. For Prod J 57(10):64-68

LeVan SL, Ross RJ, Winandy JE (1990) Effects of fire retardant chemicals on bending properties of wood at elevated temperatures. In: Res. Pap. FPL-RP-498. U.S. Department of Agriculture, Forest Service, Forest Products Laboratory, Madison

Marttila J, Möttönen V, Bütün Y, Heräjärvi H (2016) Bending properties of tangentially and radially sawn European aspen and silver 
birch wood after industrial scale thermo-mechanical modification. In: 2nd Conference on engineered wood products based on poplar/ willow wood, León, Spain, pp 113-124

Marttila J, Owusu Sarpong B, Möttönen V, Heräjärvi H (2017) Case hardening and equilibrium moisture content of European aspen and silver birch after industrial scale thermo-mechanical timber modification. In: ISCHP 2017: 6th International conference on hardwood processing. Lahti, Finland, pp 156-165

Millet MA, Gerhards CC (1972) Accelerated ageing: residual weight and flexural properties of wood heated in air at $115^{\circ} \mathrm{C}$ to $175^{\circ} \mathrm{C}$. Wood Sci 4:193-201

Mitchell P (1988) Irreversible property changes of small loblolly pine specimens heated in air, nitrogen, or oxygen. Wood Fiber Sci 3:320-335

Mohammed Raphy KM, Anoop EV, Aruna P, Sheena VV, Ajayghosh V (2011) Provenance variation in wood chemical properties of Acacia mangium willd. and Acacia auriculiformis cunn., grown in a wet humid site in Thrissur district of Kerala, South India. J Indian Acad Wood Sci 8(2):120-123

Möttönen V, Reinikkala M, Heräjärvi H, Luostarinen K (2013) Effect of compression and thermal modification on selected technical properties of European aspen and silver birch. In: Berti S, Achim A, Fioravanti M, Lihra T, Loewe Munoz V, Marchal R, Wiedenbeck J, Zanuttini R (eds) 4th International scientific conference on hardwood processing 2013, pp 165-171, Florence, Italy, 7-9 Oct 2013

Möttönen V, Bütün Y, Heräjärvi H, Marttila J, Kaksonen H (2015) Effect of combined compression and thermal modification on mechanical performance of aspen and birch wood. Pro Ligno 11(4):310-317

Nambiar EKS, Harwood CE, Kien ND (2014) Acacia plantations in Vietnam: research and knowledge application to secure a sustainable future. S For 77(1):1-10

Navi P, Girardet F (2000) Effects of thermo-hydro-mechanical treatment on the structure and properties of wood. Holzforschung 54(3):287-293

Navi P, Sandberg D (2012) Thermo-hydro-mechanical wood processing. CRC, Boca Raton

Nguyen BT (2013) Large-scale altitudinal gradient of natural rubber production in Vietnam. Ind Crops Prod 41(1):31-40

Pelit H, Sönmez A, Budakçı M (2015) Effects of thermomechanical densification and heat treatment on density and Brinell hardness of Scots pine (Pinus sylvestris L.) and Eastern Beech (Fagus orientalis L.). BioResources 10(2):3097-3111

Pelit H, Budakçı M, Sönmez A (2018) Density and some mechanical properties of densified and heat post-treated Uludağ fir, linden and black poplar woods. Eur J Wood Prod 76(1):79-87

Rautkari L, Laine K, Kutnar A, Medved S, Hughes M (2013) Hardness and density profile of surface densified and thermally modified Scots pine in relation to degree of densification. J Mater Sci 48(6):2370-2375

Riyaphan J, Phumichai T, Neimsuwan T, Witayakran S, Sungsing K, Kaveeta R, Phumichai C (2015) Variability in chemical and mechanical properties of Pará rubber (Hevea brasiliensis) trees. ScienceAsia 41:251-258

Salca E, Hiziroglu S (2014) Evaluation of hardness and surface quality of different wood species as function of heat treatment. Mater Des 62:416-423

Sandberg D, Kutnar A (2016) Thermally modified timber: recent developments in Europe and North America. Wood Fiber Sci 48:28-39
Sandberg D, Haller P, Navi P (2013) Thermo-hydro and thermo-hydromechanical wood processing: an opportunity for future environmentally friendly wood products. Wood Mater Sci Eng 8(1):64-88

Sandberg D, Kutnar A, Mantanis G (2017) Wood modification technologies - a review. iForest 10:895-908. https://doi.org/10.3832/ ifor2380-010

Santos JA (2000) Mechanical behaviour of Eucalyptus wood modified by heat. Wood Sci Technol 34:39-43

Severo ETD, Calonego FW, Sansígolo CA, Bond B (2016) Changes in the chemical composition and decay resistance of thermallymodified Hevea brasiliensis wood. PLoS One 11(3):e0151353. https://doi.org/10.1371/journal.pone.0151353

Shi JL, Kocaefe D, Zhang J (2007) Mechanical behaviour of Québec wood species heat-treated using ThermoWood process. Holz Roh Werkst 65(4):255-259

Shukla S, Sharma S (2014) Effect of high temperature processing under different environments on physical and surface properties of rubberwood (Hevea brasiliensis). J Indian Acad Wood Sci 11(2): 182-189

Shukla S, Sharma S (2018) Effect of high temperature treatment of Hevea brasiliensis on density, strength properties and resistance to fungal decay. J Indian Acad Wood Sci 15(1):87-95

Sivonen H, Maunu SL, Sundholm F, Jämsä S, Viitaniemi P (2002) Magnetic resonance studies of thermally modified wood. Holzforschung 56(6):648-654

Tabarsa T, Chui YH (1997) Effects of hot-pressing on properties of white spruce. For Prod J 47(5):71-76

Teoh Y, Don MM, Ujang S (2011) Assessment of the properties, utilization, and preservation of rubberwood (Hevea brasiliensis): a case study in Malaysia. J Wood Sci 57(4):255-266

Wahab R, Kahlid I, Sudin M, Rasat MSM, Sulaiman O, Tabert TA (2012) Changes in strength and chemical contents of oil heat treated 15-year-old cultivated Acacia hybrid. Int J Chem 4(2):90-100

Widmann R. Fernandez-Cabo JL, Steiger R (2012) Mechanical properties of thermally modified beech timber for structural purposes. Eur J Wood Prod 70(6):775-784

Xie Y, Fu Q, Wang Q, Xiao Z, Militz H (2013) Effects of chemical modification on the mechanical properties of wood. Eur J Wood Prod 71(4):401-416

Yan L, Morrell JJ (2014) Effects of thermal modification on physical and mechanical properties of Douglas-Fir heartwood. BioResources 9(4):7152-7161

Yildiz S, Gümüşkaya E (2007) The effects of thermal modification on crystalline structure of cellulose in soft and hardwood. Build Environ 42(1):62-67

Yildiz S, Gezer ED, Yildiz UC (2006) Mechanical and chemical behavior of spruce wood modified by heat. Build Environ 41(12):1762-1766

Zhou Q, Chen C, Zhao X, Tu D, Li K (2019) The effect of thermal modification by hot pressing on the some physical and mechanical properties in rubberwood (Hevea brasiliensis). Wood Res 64(2):361-371

Publisher's Note Springer Nature remains neutral with regard to jurisdictional claims in published maps and institutional affiliations. 